\title{
Anticancer Activity of L-Asparaginase Produced from Vigna Unguiculata
}

\author{
Sorial A.Moharib ${ }^{1}$ \\ 'Biochemistry Department, National Research Center, Cairo, Egypt \\ Email:samoharib@yahoo.com
}

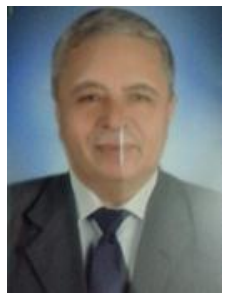

\begin{abstract}
The present study aimed to production of purified L-asparaginase from Vignaunguiculata. Different physiological parameters, such as $\mathrm{pH}$, temperature and incubation period, were optimized for growth and maximum L-asparaginase production. The optimum parameters were $37^{\circ} \mathrm{C}, 30 \mathrm{~min}$ and $\mathrm{pH} 8.5$. Maximum L-asparaginase was $886.4 \mathrm{U} / \mathrm{ml}$ with a specific activity of $1140.7 \mathrm{U} / \mathrm{ml}$ (31 fold purification with 28 \%yield) were obtained at optimum conditions. The purified L-asparaginase produced from Vignaunguiculata was used for characterization and general properties. The effect of $\mathrm{pH}$ and temperature on L-asparaginase activity as well as stability at different $\mathrm{pH}$ and temperature were determined. The optimum $\mathrm{pH} 8.5$ and $37^{\circ} \mathrm{C}$ temperature on L-asparaginase showed $100 \%$ residual activity. Stability of $\mathrm{pH}$ around 8.5 and temperature $70^{\circ} \mathrm{C}$ showed 90 and $78 \%$ residual activity at 30 and 60 min respectively. The Lasparaginase showed high stability at alkaline $\mathrm{pH}(\mathrm{pH}$ 8.5) when incubated for up to 6oh.The molecular weight of the produced L-asparaginase was close to $68.5 \mathrm{kDa}$. Cytotoxic activity of Lasparaginase was examined in vitro using four carcinoma cell lines. L-aspargenase has higher effective in growth inhibition against HEPG2 and HCT-116 but lower against HELLA and MCF7 carcinoma cell lines. The data show that L-aspargenase has a higher cytotoxic activity against HEPG2 and HCT116, revealed higher percentage of cell death, indicating antitumor properties, and demonstrate direct effect on cancer cell proliferation of HEPG2 and HCT116. Therefore, Vignaunguiculata was considered to be a suitable source for production of Lasparaginase has higher activity and good stability. Purified L-asparaginase obtained from Vignaunguiculata could be employed in drug chemotherapy and treatment of cancer.
\end{abstract}

Keywords: Seed, L-asparaginase, Cytotoxicity.

Citation | Sorial A.Moharib (2018). Anticancer Activity of LAsparaginase Produced from VignaUnguiculata. World Scientific Research, 5(1): 1-12.

History:

Received: 11 September 2017

Revised: 27 December 2017

Accepted: 4 January 2018

Published: 10 January 2018

Licensed: This work is licensed under a Creative Commons

Attribution 3.0 License (c)) E

Publisher:Asian Online Journal Publishing Group
Funding: The author acknowledges the National Research Center, Dokki, Cairo, Egypt. Was funded the project number 9100108.

Competing Interests: The authors declare that they have no conflict of interests.

Transparency: The authors confirm that the manuscript is an honest, accurate, and transparent account of the study was reported; that no vital features of the study have been omitted; and that any discrepancies from the study as planned have been explained.

Ethical: This study follows all ethical practices during writing.

\section{Contents}

1. Introduction

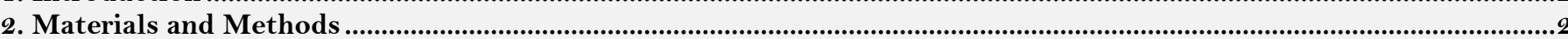

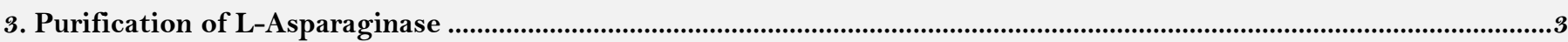

4. Characterization................3

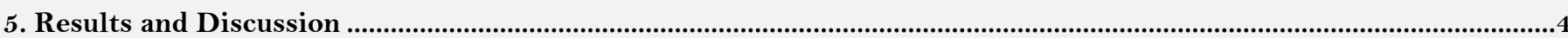

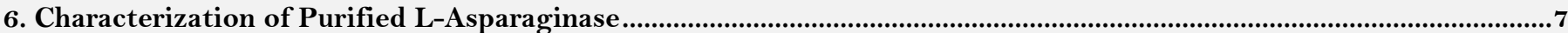

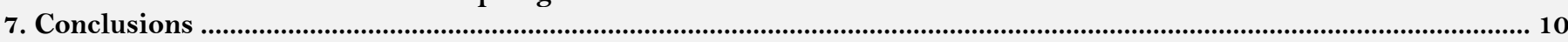

References 


\section{Introduction}

L- Asparaginase is widely distributed in both prokaryotic and eukaryotic cells and has been intensively studied over the last decades. Legume seeds have played in a significant role as protein source in the human diet of the peoples in many parts of the world. Enzymes are proteinaceous in nature in various organs produced by many cells in different unicellular and multicellular organisms. Different types of enzymes are produced based on the adaptation to the environment where the living organisms live to tune the metabolic pathways according to their adapted changes. L-asparaginase enzymes (E.C.3.5.1.1) are widely distributed among plants, animals and microorganisms [1-4]. Esherichia coli, Erwiniacarotovora, Bacillus sp. were found to be the most commonly organisms used for production of L-asparaginase [5-7]. Different animal organs were also used for production of L-asparaginases [1,8]. L- asparaginase was detected in different plant species used as a source of protein for human food [4, 9]. Recently, several investigators search some plant sources for L-asparaginase production to meet the increase continuous need for L-asparaginases [10-13]. L-asparagine is the most abundant metabolite for the storage and transport of nitrogen that is utilized in protein biosynthesis [14-16]. The L-asparaginase (E.C.3.5.1.1) an aminohydrolasecatalyses effect involved asparagine hydrolysis to yield L-aspartate and ammonia [Q, 14, 17]. L-glutamine to L-glutamate as well as L-asparagine transamination [17, 18]. Several investigators [8, 14, 19] reported an internal and external L-aspargenases were biochemically and genetically distinct in different plants. Moreover, plant source L-asparaginases are evolutionarily and structurally distinct from the bacterial Laspargenases [7, 20] and Kishor, et al. [21]. Recently, L-asparaginase has attracted much attention in both pharmaceutical and industrial applications [8, 22, 23]. L-asparaginase used as chemotherapeutic agent for treatment of human cancer and acts as a catalyst in the breakdown of asparagine, as nutritional requirement for both normal and cancer cells, to aspartic acid in vitro and in vivo [21, 24, 25]. L-asparaginase from plants origin leads to the death of leukaemic and tumor cells due to catalyses the hydrolysis of asparagine to aspartic acid [6, 11, 23]. L-asparaginase was used to treat hepatocellular cell lines in vitro and in vivo to examine the therapeutic efficacy $[22,26,27]$. L-asparaginase is a therapeutically important protein used in combination with other drugs in the treatment of acute lymphocytic leukemia, lymphosarcoma, melanosarcoma and different kinds of cancer [6, 28$30]$. Cancer cases are gradually increasing and leading the cause of death in both developed and developing countries $[27,31,32]$. Among the most common types of cancers are lymphomas, leukemias, colorectal, liver, breast and prostate [6, 13, 32]. [33]. Currently, the most commonly use cancer chemotherapy includes mainly alkylating agents, antimetabolites and natural anticancer agents [23, 34-36]. The microbial L-asparaginaseshave only been produced commercially as a drug in the treatment of acute lymphoblastic leukemia [21, 37, 38]. Different studies [22,39] discovered plant natural products have more toxic to cancer cells than normal cells in screening and developed chemotherapy drugs [27, 28, 35, 40]. Important progress has been made in cancer chemotherapy include plant derived drugs with cytotoxic activity as the treatment of cancer [25, 26, 31]. Other workers [32, 41]. Established natural products as anti-cancer properties in vivo or in vitro. However, the continuous need of therapeutic enzymes in biotechnology and medicine for cancer treatment leads to the present study was done aimed to production and purification of a commercially L-aspargenase from plant seeds as inexpensive and suitable sources. Cytotoxic activity of the purified L-aspargenase produced from Vignaunguiculata was examined against four different carcinoma cell lines in vitro. Moreover, seed is a member of Leguminecea family grown in different parts of the world and used as protein source for human food.

\section{Materials and Methods}

\subsection{Materials}

2.1.1-Vigna unguiculata seeds were obtained from the local market, Cairo, Egypt. Vignaunguiculata seeds were dried and ground to a very fine powder, sifted through a 16 mesh sieve, packed in bags, and stored till used immediately.

2.1.2-TCA and DEAE-Sepharose was purchased from Sigma Chemical Co. (USA).

2.1.3- Sephacryl S-200 and standards protein were purchased from Pharmacia, Uppsala, Sweden.

Preparation of crude extract

A known weight of Vignaunguiculata seeds powder $(50 \mathrm{~g})$ were homogenized in 20mMTris-HCl buffer (pH8.0) containing $10 \%$ glycerol, $50 \mathrm{mM} \mathrm{KCl}, 12.5 \mathrm{mM} \beta$-mercaptoethanol, and $1 \mathrm{mM}$ phenylmethylsulfonylfloride (PMSF), homogenized and shaken at $200 \mathrm{rpm}$ using rotary shaker for $2 \mathrm{~h}$ at $30^{\circ} \mathrm{C}$. The samples were stand for one hour, then filtered and centrifuged at 15000 for 30 min using cooling centrifuge(Sigma 2 K15). The supernatant was collected and designated as crude enzyme extract. Different factors were studied on crude L-asparaginase activity [42].

\subsection{Effect of Substrate Concentration}

Effect of substrate concentration on the activity of crude L-asparaginase was determined by incubation crude enzyme with different substrate concentrations (50,100, 150,200, and $250 \mathrm{mM})$, then L-asparaginase activity was determined as previous.

\subsection{Effect of Reaction Time}

The optimization of reaction time is needed to determine the highest amount of L-asparaginase production [20]. Effect of reaction time for L-asparaginase was determined by incubation the reaction mixture for different periods of time (10-90 minutes) at $37^{\circ} \mathrm{C}$ and $\mathrm{pH} 8.5$, then L-asparaginase activity was determined as previous.

\subsection{Effect of $\mathrm{pH}$}

The effect of $\mathrm{pH}$ value on L-asparaginase activity was determined by assaying the enzyme activity at different $\mathrm{pH}$ values ranges from 3.0 to 11.0 under the standard conditions [42]. 


\subsection{Effect of Temperature}

The effect of temperature on L-asparaginase activity was determined by assaying the enzyme activity at different temperature range from 10 to $90^{\circ} \mathrm{C}$. Like most chemical reactions, the rate of an enzyme-catalyzed reaction increases as the temperature is raised. A ten degree Celsius rise in temperature will increase the activity of most enzymes by 50 to $100 \%$. Variations in reaction temperature as small as 1 or 2 degrees may introduce changes of 10 to $20 \%$ in the results [43].

\section{Purification of L-Asparaginase}

\subsection{Precipitation with Ammonium Sulfate}

L-asparaginase was precipitated by addition of (NH4) $2 \mathrm{SO} 4$ at $0-80 \%$ saturation and kept overnight at $4{ }^{\circ} \mathrm{C}$. The solutions were allowed to stand at room temperature and centrifuged at $15000 \mathrm{rpm}$ for $30 \mathrm{~min}$. The precipitates were re-suspended in $25 \mathrm{mM}$ phosphate buffer ( $\mathrm{pH} 8.5$ ) and extensively dialyzed against the same buffer ( $\mathrm{pH} 8.5$ ) for $48 \mathrm{~h}$. The dialyzed samples were centrifuged using cooling centrifuge. The collected and concentrated supernatant was used for L-aspargenase studies. L-aspargenase was purifiedand used for characterization studies according to the methods of Palmieri, et al. [44].

\subsection{Anion Exchange Chromatography}

The (NH4)2 SO4 precipitated samples were concentrated and applied to a DEAE-Sepharose column $(1.6 \times 15 \mathrm{~cm})$ previously equilibrated with $25 \mathrm{mMTris}-\mathrm{HCl}$ buffer $(\mathrm{pH} 8.5)$. The $(\mathrm{NH} 4)_{2} \mathrm{SO} 4$ precipitated samples were washed with three column volumes of the same buffer and eluted with $25 \mathrm{mM}$ Tris-HCl buffer $(\mathrm{pH} 8.5)$. The column was washed at a flow rate of $60 \mathrm{ml} / \mathrm{h}$ with $100 \mathrm{ml}$ of the same buffer, and a 0-O.1 M KCL was applied. Two column volumes of eluted fractions containing high L-aspargenase activity were collected and concentrated. Two peaks of protein were eluted with two L-asparaginase activity fractions (F1 and F2).

\subsection{Gel Filtration Chromatography}

Gel filtration was performed according to Aworh and Nakai [45]. The concentrated eluted fractions (F1 and F2) were pooled and applied onto a Sephacryl S-200 column $(1.8 \times 85 \mathrm{~cm})$ and eluted with $25 \mathrm{mMTris}-\mathrm{HCl}$ buffer $(\mathrm{pH} 8.5)$ containing 0.15M KCL. The eluted fractionswere assayed for L-aspargenase activities as described by Dharmsthiti and Luechai [46]. The active samples were pooled and dialyzed against 25mM Tris-HCL buffer (pH 8.5) containing $0.1 \mathrm{M} \mathrm{KCl}$. After concentration, the solutions were applied onto a Sephacryl S-200 column and eluted with the same buffer at a flow rate of $30 \mathrm{ml} / \mathrm{h}$ and $3 \mathrm{ml}$ fractions were collected as purified products.

\subsection{Protein Determination}

Protein concentration was estimated according to the methods of Bradford [47] using bovine serum albumin as standard.

\subsection{L-Aspargenase Assay}

The activity of L-asparaginase was measured based on Lasparaginase catalyzes L-asparagine to L-asparatate and Ammonia using Nesslerization method [48]. L-asparaginase activity from Vignaunguiculata seed extract was determined by adding $0.5 \mathrm{ml}$ of crude enzyme to $2 \mathrm{ml}$ of $200 \mathrm{mM}$ prepared L-asparagine, then $2 \mathrm{ml}$ of potassium phosphate buffer (0.05M, pH 8.0) was added, mixed gently and incubated at $37^{\circ} \mathrm{C}$ for 30 minutes. The reaction mixture was stop by $1 \mathrm{ml}$ of $1.5 \mathrm{M}$ trichloroacetic acid (TCA) and mixture was centrifuged at $15000 \mathrm{rpm}$ for 10 minutes using cooling centrifuge to remove the precipitate. The ammonia concentration was determined in the supernatant by adding Nessler's reagent and left at room temperature for $10 \mathrm{~min}$. The blank was prepared by adding enzyme after TCA addition and the developed color was measured at 450nm [46]. One unit of L-asparaginase activity is defined as the amount of the enzyme that liberates $1 \mu \mathrm{mol}$ of ammonia per min under assay conditions.

\section{Characterization}

\subsection{Determination of Molecular Weight}

The average molecular weight of L-aspargenase was determined by gel filtration chromatography [5, 49]. UsingSephacryl S-200 column (1x100). The sample was applied through a glass column packed with pre calibrated Sephacryl S-200 column (1x100) equilbrated and developed with $25 \mathrm{mM}$ standard buffer. Fractions of $0.5 \mathrm{ml}$ were collected at a flow-rate of $0.05 \mathrm{ml} / \mathrm{min}$. The following known molecular weight standards were used for the molecular weight determination under optimum conditions. The known molecular weight markers were used for calibration of the column of dehydrogenase $(150 \mathrm{kDa})$, phosphorylase $(97 \mathrm{kDa})$, bovine serum albumin $(67 \mathrm{kDa})$, pepsin $(35.5 \mathrm{kDa})$, carbonic anhydrase $(29 \mathrm{kDa})$, trypsin $(24 \mathrm{kDa})$, myoglobin $(17.8 \mathrm{kDa})$, lysozyme $(14 \mathrm{kDa})$ and cytochrome C $(12,4 \mathrm{kDa})$.

\subsection{Effect of $\mathrm{pH}$ on L-Asparaginase Activity}

This can be achieved using different $\mathrm{pH}(3.0-11.0)$, incubated in a water bath at $37^{\circ} \mathrm{C}$ for 30 minutes, then the activity of L-asparaginase activity was assayed.

\subsection{Effect of pH on L-Asparaginase Stability}

Purified enzyme was incubated at different $\mathrm{pH}$ values ranging between 3.0 and 11.0 at $37^{\circ} \mathrm{C}$ for one hour. The L-aspargenase activity and residual activity were measured after assaying enzyme activity [50].

\subsection{Effect of Temperature on L-Asparaginase Activity}

The effect of temperature on L-asparaginase activity was determined by assaying the enzyme activity at different temperature range from 10 to $90^{\circ} \mathrm{C}$. Like most chemical reactions, the rate of an enzyme-catalyzed 
reaction increases as the temperature is raised. A ten degree Celsius rise in temperature will increase the activity of most enzymes by 50 to $100 \%$.

\subsection{Effect of Temperature on L-Asparaginase Stability}

A purified enzyme was incubated in a water bath for different temperatures $(20,25,30,35,40,45,50,55$ and $60^{\circ} \mathrm{C}$ ) for one hour, then immediately transferred into an ice bath. L-asparaginase activity was assayed for each treatment, then activity and the remaining activity was determined.

\subsection{Cytotoxicity and Anticancer Activity in Vitro}

Different four cancer cells, colon (HCT-1 16), liver (HEPG2), breast (MCF-7) and cervical (HELLA). Breast cancer (MCF-7) and cervical cancer were used in the present study in vitro. Cytotoxicity was done according to the method of Itharat, et al. [51]. IC50 was calculated by analysis between surviving fraction and concentration [52]. In vitro anticancer activity was determined [36].

\section{Results and Discussion}

\subsection{Extraction L-Asparaginase from VignaUnguiculata Seeds}

L-Asparaginase was extracted from Vignaunguiculataseeds using the homogenization method to obtain crude enzyme. Results in Table (1) showed higher total activity of crude L-asparaginase in the extracts of Vignaunguiculata seed was $18540 \mathrm{U}$. Results also showed the maximum and specific activity of L-asparaginase were less $(309 \mathrm{U} / \mathrm{ml}$ and $36.8 \mathrm{U} / \mathrm{mg}$ respectively). According to these results Vignaunguiculataseed was used forLasparaginase production, purification, characterization and applications. It has been reported that plant is a source of protease, therefore phenylmethylsulfonyl fluoride (PMSF) was used in extraction as an inhibitor for serine proteases and alkaline proteases which was active in alkaline $\mathrm{pH}$ and may degrade L-asparaginase [20, 21] that was active in alkaline $\mathrm{pH}(\mathrm{pH} 8.5)$.

Table-1. Purification of L-asparaginase produced from Vigna unguiculata seeds.

\begin{tabular}{|c|c|c|c|c|c|c|c|c|}
\hline Ingradients & $\begin{array}{l}\text { Total } \\
\text { volume } \\
(\mathrm{ml})\end{array}$ & $\begin{array}{l}\text { Protein } \\
(\mathrm{mg} / \mathrm{ml})\end{array}$ & $\begin{array}{l}\text { Activity } \\
\text { units } \\
(\mathrm{U} / \mathrm{ml})\end{array}$ & $\begin{array}{l}\text { Specific } \\
\text { activity } \\
(\mathrm{U} / \mathrm{mg})\end{array}$ & $\begin{array}{l}\text { Total } \\
\text { activity } \\
\text { units(U) }\end{array}$ & $\begin{array}{l}\text { Total } \\
\text { protein } \\
(\mathrm{mg})\end{array}$ & $\begin{array}{l}\text { Purification } \\
\text { fold }\end{array}$ & $\begin{array}{l}\text { Yield } \\
(\%)\end{array}$ \\
\hline Crude L-aspargenase & 60 & 8.4 & 309 & 36.8 & 18540 & 504 & 1 & 100 \\
\hline (NH3)4SO4 ppt & 26 & 6.02 & 180 & 72.4 & 11332.05 & 156.52 & 2 & 61 \\
\hline \multicolumn{9}{|l|}{ DEAE-Sepharose } \\
\hline L-aspargenase (F1) & 6.4 & 2.4 & 835.7 & 348.2 & 5348.5 & 15.36 & 10 & 29 \\
\hline L-aspargenase $\left(\mathrm{F}_{2}\right)$ & 5.2 & 1.04 & 462.2 & 444.4 & 2403.4 & 5.41 & 12 & 13 \\
\hline Sephacryl S-200 & 2.4 & 0.6 & 886.4 & 1140.7 & 5236 & 1.44 & 31 & 28.24 \\
\hline
\end{tabular}

\subsection{Optimum Conditions for L- Asparaginase Activity}

L-asparaginase enzyme was extracted from Vignaunguiculata seedand used foroptimum conditions studies for Lasparaginase activity. These conditions include substrate concentration, reaction time, $\mathrm{pH}$ and temperature. Kozak and Jurga [53] and Shanmugaprakash, et al. [13] reported the L-asparaginase activity may affect the change of these parameters. Therefore, It is possible to increase the enzyme activity by increasing substrate concentration, reaction, $\mathrm{pH}$ and temperature.

\subsection{Effects of Substrate Concentration}

Different concentrations $(10,50,100,150,200$, and $250 \mathrm{mM})$ of substrate (asparagine) for L-aspargenase were used to determine the optimum substrate concentration for L- asparaginase activity. Results in Figure (1) showed that the activity of L- asparaginase was increased gradually with the increase in L-asparagine concentration. Maximum activity of L-asparaginase was obtained at the substrate concentration level was $200 \mathrm{mM}(332.7 \mathrm{U} / \mathrm{ml})$.

The concentration level $(200 \mathrm{mM})$ of L-asparagine consider as the optimum substrate for L-asparaginase activity. These results were agreed with other workers $[10,54]$ who found that there is a positive relationship between the enzyme activity and substrate concentration, hence the reaction was increased with the increase of substrate concentration when the L-asparaginase concentration was constant until the maximum rate [55]. In addition, substrate inhibition will sometimes occur when excessive amounts of substrate are present in the reaction mixture [12]. According to the present results (Figure 1), L-asparaginase produced by Vignaunguiculataseeds was reached the steady state when the L- asparagine concentration was $200 \mathrm{~m}$ M. Similar results were reported by other investigators $[10,12,22]$ established that the consumption of high substrate concentration indicates high activity of L-asparaginase in the treatment of the late stages of acute lymphoblastic leukemia in the blood of children. However, the optimum substrate concentration of enzyme activity from hot pepper of Capasciumannium L. was $33 \mathrm{mM}$ using catechol as a substrate $[25,56]$.

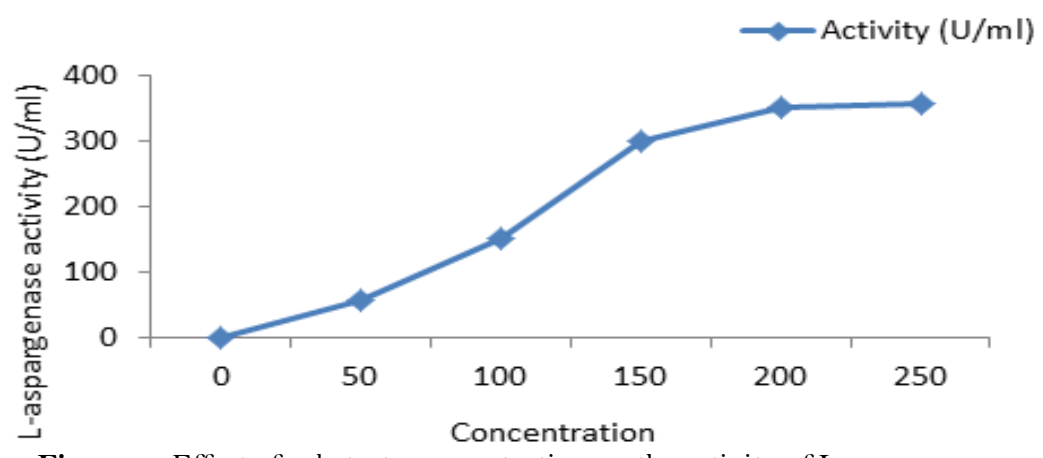

Figure-1. Effect of substrate concentration on the activity of L-aspargenase. 


\subsection{Effect of Reaction Time}

L-asparaginase activity obtained by seed was determined at different reaction time (10-90 minutes). Results in Figure (2) showed that the optimum incubation period was 30 minutes, the enzyme activity was $420 \mathrm{U} / \mathrm{ml}$. According to these results, it has been concluded that 30 minutes of incubation was suitable for reaching maximum L-aspargenase activity. Different studies reported that the reaction time is an important factor for determination of the enzyme activity and it was preferred to use methods with short time incubation to determine the enzyme activity $[57,58]$. Moreover, there is a linear relationship between enzyme activity and reaction time $[8,55]$.

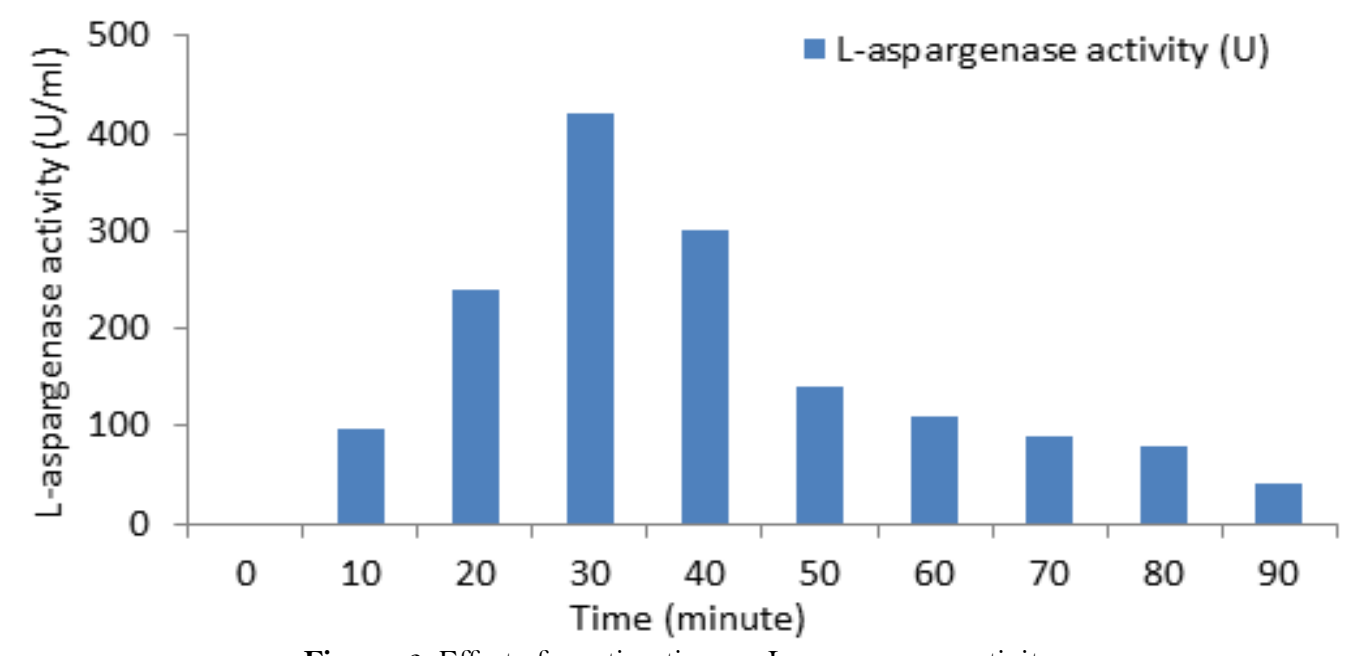

Figure-2. Effect of reaction time on L-aspargenase activity.

\subsection{Effect of $\mathrm{pH}$}

Effect of $\mathrm{pH}$ on the activity of L-asparaginase activity produced by Vignaunguiculata seed was studied. Result illustrated in Figure (3) showed that maximum l-asparaginase activity was obtained when $\mathrm{pH}$ of the reaction mixture was adjusted to 8.5 , at this value, the enzyme activity was $400 \mathrm{U} / \mathrm{ml}$. Similar results were obtained by several investigators [5, 13]. The present observation was also reported by other investigators [12, 59]. Indicated that many L-asparaginase from plant origin had higher activities at $\mathrm{pH}$ ranged from 8.0 to 8.5. Moreover, alkaline $\mathrm{pH}(8.0-10)$ showed optimum $\mathrm{pH}$ for most bacterial L-asparaginases activity [60,61]. It has been reported that most plant L-asparaginases have its maximum activity in alkaline $\mathrm{pH}$, and was determined in $\mathrm{pH}$ range of 7.5, 8.0 and 8.5 due to the balance between L-aspartic acid and L-aspartate [11,58]. In general most plants show maximum enzyme activity at or near neutral $\mathrm{pH}[60]$. The decrease or increase in $\mathrm{pH}$ value will be changes in the reaction mixture, resulting enzyme denaturation [27]. On the other hand, the effect of $\mathrm{pH}$ on enzyme activity resulted from its effect on the substrate ionization Abdel-Fattah and Olama [57]. Khalaf, et al. [12] found favorable balance for the connection with the substrate L-asparagine and they reported that the optimum $\mathrm{pH}$ was 7.0. In addition $\mathrm{pH} 8.0$ was optimum for enzyme obtained from Irvingiagabonnensis [42].

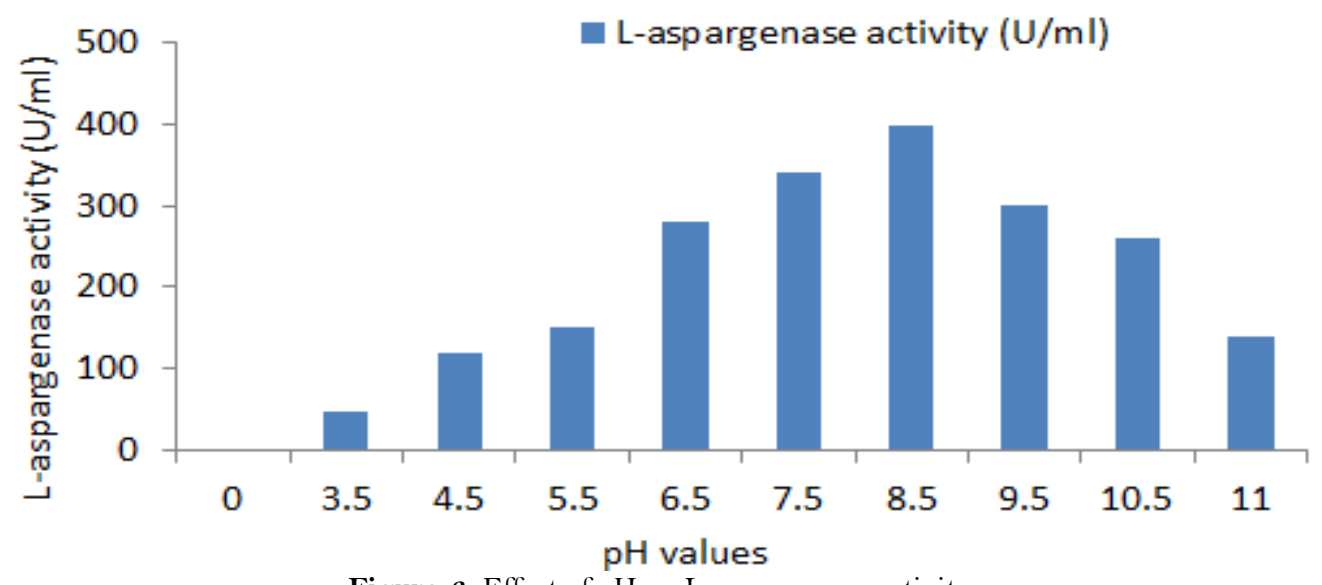

Figure-3. Effect of $\mathrm{pH}$ on L-aspargenase activity

\subsection{Effect of Temperature}

Reaction mixture of L-asparaginase obtained from Vignaunguiculata seed was assayed at different temperatures $\left(25,30,35\right.$ and $\left.40^{\circ} \mathrm{C}\right)$. Other investigators reported that these range of temperature was the most suitable for enzyme activity $[57,58]$. Results illustrated in Figure (4) showed that the maximum activity of L-asparaginase was obtained at $37^{\circ} \mathrm{C}$ of the reaction mixture. The enzyme activity was increased to $490 \mathrm{U} / \mathrm{ml}$ at this temperature. Moreover, L-asparaginase isolated from most organisms has maximum activity at $37^{\circ} \mathrm{C}[37,46,58]$. The increase or decrease in reaction temperature above or below the optimum temperature cause a decrease in enzyme activity. L-asparaginase from most organisms have its maximum activity at $37^{\circ} \mathrm{C}[55,61]$. While the increase or decrease in the incubation temperature above or below the optimum temperature cause a decrease in enzyme activity. These variations in the activity of $\mathrm{L}$ - asparaginase proved that the suitable temperature for asparaginase reaction to have maximum activity was $37^{\circ} \mathrm{C}$, while the activity was decreased when the temperature was above optimum or below the temperature. Other investigators $[58,62]$ found that the temperature at which polyphenol oxidase from Thymus logicaulis showed highest activity was in range of $25-30^{\circ} \mathrm{C}$ and then decreased at temperature above $40^{\circ} \mathrm{C}$. while peroxidase was highly active at $40^{\circ} \mathrm{C}$ and cost its activity at higher temperature [63]. 


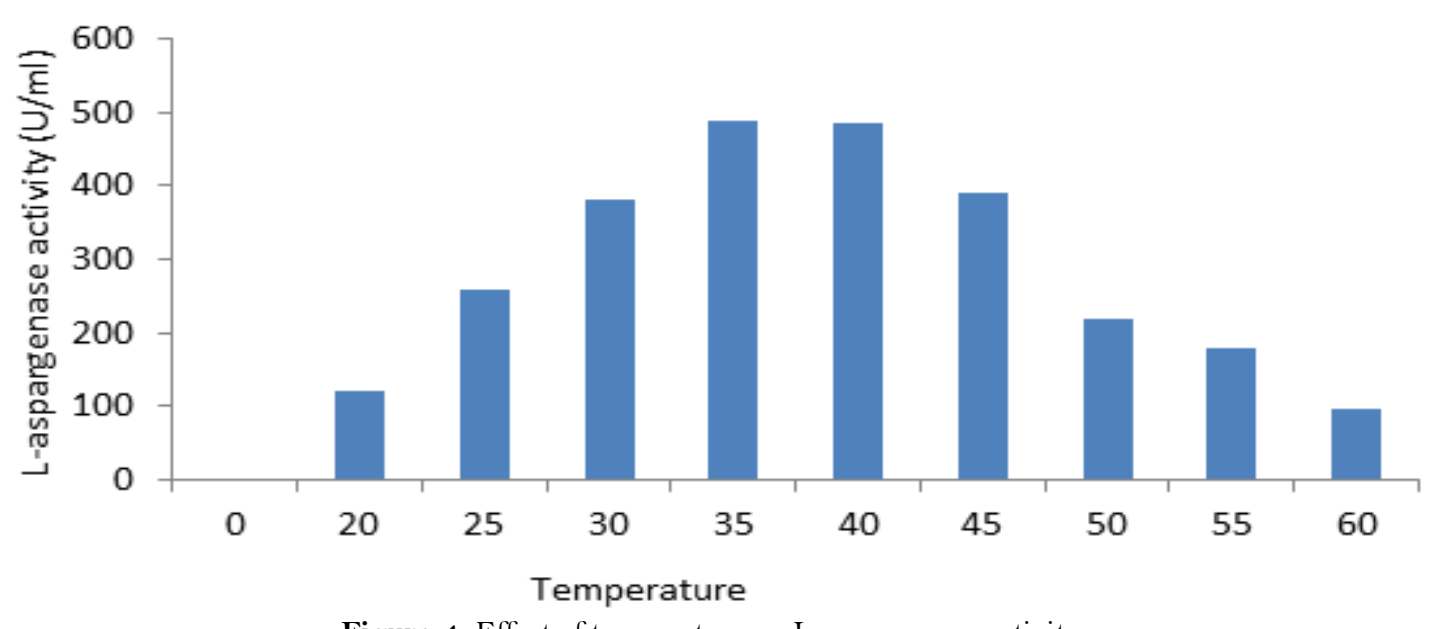

Figure-4. Effect of temperature on L-aspargenase activity.

\subsection{Purificationof L-AsparaginaseExtracted from VignaUnguiculataSeeds}

Crude L-asparaginase extracted from seeds was precipitation from Vignaunguiculataseeds crude extracts using ammonium sulfate $(20 \%,-80 \%$ respectively) as mentioned in Table (1). L-asparaginase was purified in two steps, ion exchange chromatography by DEAE-Sepharose and gel filtration chromatography by Sephacryl S-200. The results of purification steps of L-asparaginase fromVignaunguiculataseedsare summarized in Table 1. The elution profile ofthe chromatography on DEAE-Sepharose column (Figure 5)showed two peaks (F1 and F2) of proteins (15.36 and $5.41 \mathrm{mg}$ respectively) with L-asparaginase activity. Peak one with the highest L-asparaginaseactivity (5348.5U) was applied onto a Sephacryl S-200 column (Figure 5). L-asparaginase Iwas purified 10-fold with a specific activity 348.2 units/mgprotein. L-asparaginase I was proved to be pure afterSephacryl S-200 column (Figure 5). Specific activity of purified L-asparaginase was $1140.7 \mathrm{U} / \mathrm{mg}$ with purified 31 -fold. Similar results were obtained by other investigators [10,64].

\subsection{Ion Exchange Chromatography.}

L-asparaginase extracted from Vignaunguiculataseeds of seeds was purified by ion-Exchange chromatography using DEAE- Sepharose. DEAE- Sepharose was used for purification due to their easy to simplicity prepare, multiple use and has high bioseparation capacity [45, 65].According to results obtained from this study, optimum $\mathrm{pH}$ for L-asparaginase activity which was $\mathrm{pH} 8.5[12,55]$. According to these findings, ion exchanger DEAESepharose was used for purification of Figure (5):

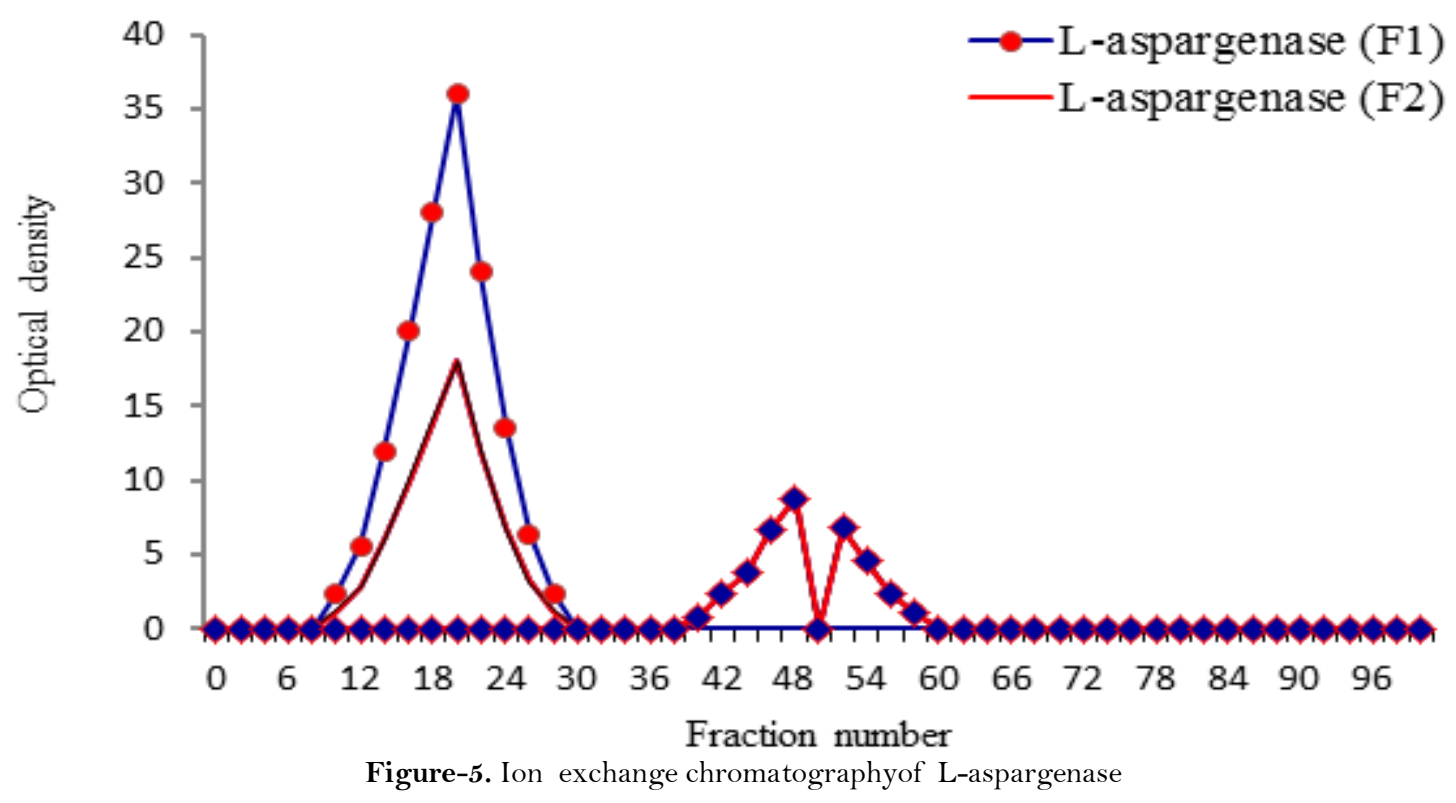

Ion exchange chromatography for purification of L-asparaginase produced from seeds using DEAE- Sepharose column $(2 \times 23 \mathrm{~cm})$ with a flow rate of $20 \mathrm{ml} /$ hour. Results illustrated in Figure $(5)$ showed that the third peak that eluted in fraction numbers 20 to 48 has L-asparaginase activity that reaches $1297.9 .0 \mathrm{U} / \mathrm{ml}$. Fractions represents L-asparaginase active were collected and pooled, then protein concentration, L-asparaginase activity, specific activity was estimated. Results indicated in Table (1) showed that the maximum L-asparaginase activity and specific activity in the L-asparaginase concentrate were $886.4 \mathrm{U} / \mathrm{ml}$ and $1140.7 \mathrm{U} / \mathrm{mg}$ respectively, with 31 - fold of purification. Ion exchange chromatography was applied for purification of L-asparaginase by many investigators $[9,27,64]$. Partially purified L-asparaginase obtained from the ion exchange chromatography was further purified by gel filtration chromatography.

\subsection{Gel Filtration Chromatography}

Gel filtration chromatography was used in the purification of L-asparaginase produced by Vignaunguiculataseed after purification by ion exchange chromatography. $5 \mathrm{ml}$ of partially purified L-asparaginase was applied on Sephacryl S-200 column $(1.8 \times 85 \mathrm{~cm})$ which previously equilibrated with $0.1 \mathrm{M}$ potassium phosphate buffer $(\mathrm{pH}$ 8.0). which allows ability of separation with high degree of purification $[7,21,65]$. Furthermore, gel filtration is the 
simplest and separates molecules [66]. Proteins were eluted at a flow rate of $20 \mathrm{ml} /$ hour. Protein peaks were determined. Results in Figure (6) showed that only one peak represents L-asparaginase activity was appeared after elution with potassium phosphate buffer. Fractions representing L-asparaginase activity were pooled, then protein concentration, L-asparaginase activity and specific activity were measured in $20 \mathrm{ml}$ of enzyme concentrate Figure (6). Results in Table (1) showed that there is an increase in both activity of purified enzyme (886.4 U/ml) and specific activity $(1140.7 \mathrm{U} / \mathrm{mg}$ ) with a purification fold 31 with an increase in the yield of L-asparaginase (28-.24\%). Partial purification of L-asparaginase from chicken liver using Sephadex G-200 (20-80 ammonium sulfate precipitation) gives specific activity of $158.11 \mathrm{U} / \mathrm{mg}$ with $17 \%$ yield [ 8 ]. Purification of L-asparaginase produced by Streptomyces using precipitation with ammonium sulfate $45-85 \%$ and Sephadex G-200 gel filtration gave a maximum specific activity of $63.0 \mathrm{U} / \mathrm{mg}$ with 82.9 fold of purification with $2.18 \%$ yield demonstrated [3]. On the other hand, L-asparaginase from Enterobacteraerogeneswas purified by gel filtration with Sephacryl S-100 gives 10-fold of purification with a specific activity of $55 \mathrm{IU} / \mathrm{mg}$ and recovery of $54 \%$ [67].

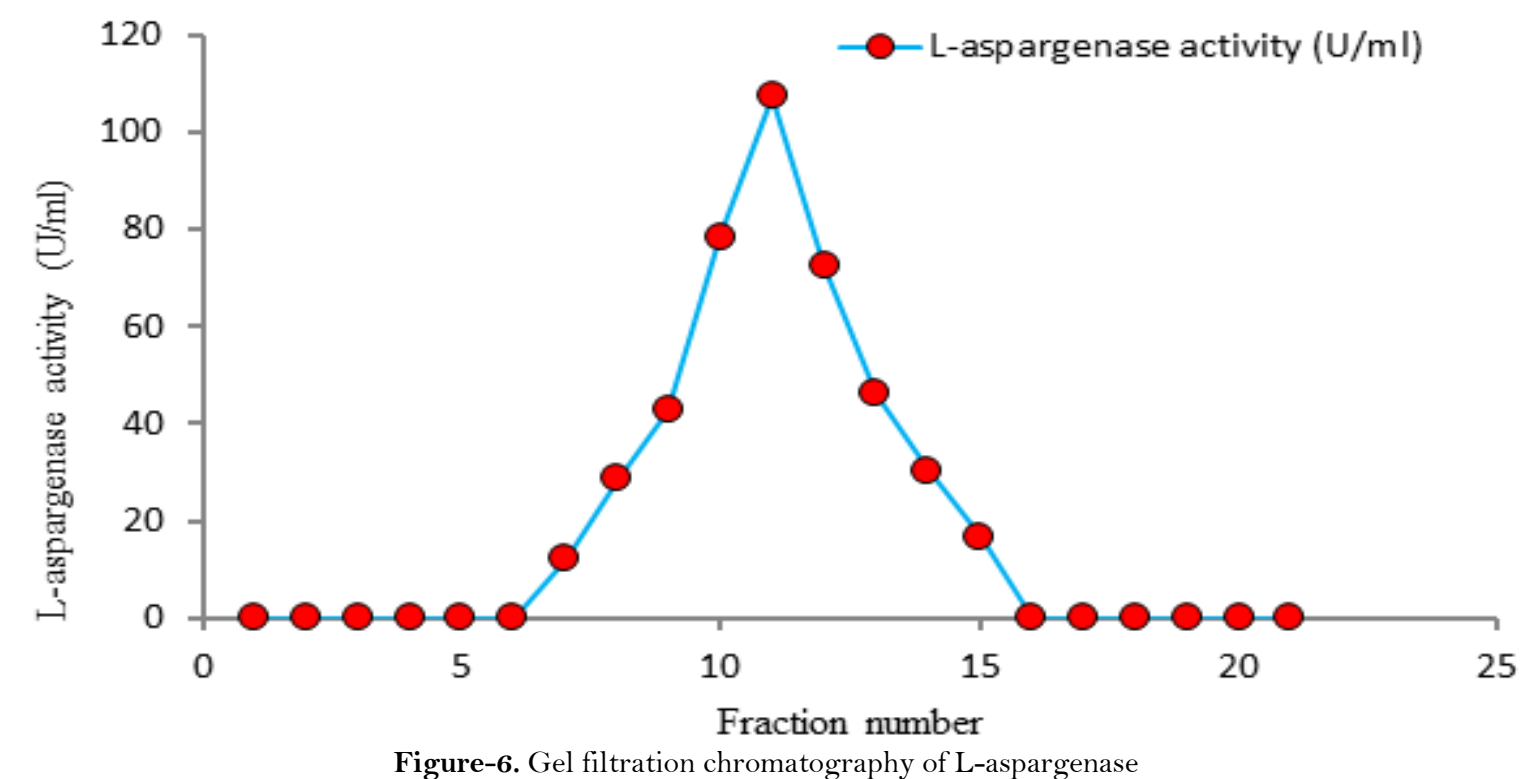

\section{Characterization of Purified L-Asparaginase \\ 6.1. Molecular Weight of L-Asparaginase}

Molecular weight of the purified L-asparaginase produced byVignaunguiculata seedwas determined by gel filtration chromatography using Sephacryl S-200 and different known molecular weight standard proteins as Pepsin (14000 Dalton), Trypsin (20000 Dalton), Urease (430000 Dalton), Bovine serum albumin (67000 Dalton), phosphorylase $(97 \mathrm{kDa})$, dehydrogenase $(150 \mathrm{kDa})$,and separately were applied and eluted individually. Results showed that L-asparaginase has a molecular weight of $68,5 \mathrm{KeloDalton}$. These results are in the range with those obtained by many investigators [43, 58] reported that the molecular weight of L-asparaginase from $P$. sativumseeds was 68 KDa using Sephadex LH-20 and 69 KDa using Sephacryl S-200 chromatography. Other studies found the molecular weight of L-asparaginase produced from $\mathrm{P}$. sativum was $58 \mathrm{KDa}[12,13,68]$ However, the molecular weight of L-asparaginase by Sephacryl S-200 yielded a value of $79 \mathrm{kDa}$. Vignaunguiculata with a molecular weight of 70000 Dalton using Sephacryl S-200 chromatography [7, 10, 21]. On another hand the molecular weight of L-asparaginase purified from Withaniasomnifera was detected by polyacrylamide-gel electrophoresis revealed dense bands along the gel with purified enzyme [11,43] and stated to have 72000 Dalton by gel chromatography technique [4] This finding is in agreement with molecular weights for L-asparaginases from Vignaunguiculata $(70 \mathrm{kDa})$ and Lupinuspolyphyllus $(75 \mathrm{kDa})$ as reported by other investigators [10, 21, 69]. A medium molecular weight of $58 \mathrm{kDa}$ was detected for L-asparaginase from pea leaves [70]. Bacterial Lasparaginases, the molecular weight ranged from 140 to $160 \mathrm{kDa}[24,53,60]$. A very low molecular weight of 11.2 $\mathrm{kDa}$ was detected for Streptobacillus sp. KK2S4 L-asparaginase [58]. However, Molecular weight of Lasparaginase was differed according to the organisms. Results of characterization showed that the molecular weight of L-asparaginase was 68,5 Kelodalton, and the optimum $\mathrm{pH}$ for enzyme activity and stability was $\mathrm{pH} 8.5$, while the optimum temperature for enzyme activity and stability was $37^{\circ} \mathrm{C}$ and $40^{\circ} \mathrm{C}$ respectively.

\subsection{Effect of $\mathrm{pH}$ on L-Asparaginase Activity}

The $\mathrm{pH}$ for L-asparaginase activity was determined at different $\mathrm{pH}$ values ranging from $\mathrm{pH} 3.0$ to $\mathrm{pH}$ 11.0. Results in Figure (3) showed higher L-asparaginase activity $(622 \mathrm{U} / \mathrm{ml}$ and $632 \mathrm{U} / \mathrm{ml})$ at $\mathrm{pH} 8.0$ and 8.5 respectively. These effect may be attributed to the hydrolysis and breakdown of asparagine by L-asparaginase [2, 14]. These results are in agreement with those reported by other investigators [9] found the optimum activity of L-asparaginase at $\mathrm{pH}$ 8.5. E.coli and $S$. marsconshave an optimum activity at $\mathrm{pH} 8.6$ [2, 68]. While the optimum $\mathrm{pH}$ for L-asparaginase activity of Bacillus spp. was at pH 7.0 [60]. This property of the enzyme make clear that the enzyme produced by plant under the present study has effective carcinostatic property, because the physiological $\mathrm{pH}$ is one of the perquisites for antitumor activity [24]. However, L-asparaginase activity below pH 8.0 was not effective tumor treatment $[27,33]$. The purified enzyme would be useful because $80 \%$ of the enzyme activity was retained at $\mathrm{pH} 7.5$.

\subsection{Effect of Temperature on L-Asparaginase Activity}

Temperature is an important factor affects enzyme activity. Therefore optimum temperature for L-asparaginase activity was determined and the residual activity was assayed at different temperatures. Results in Figure (4) showed that $37^{\circ} \mathrm{C}$ was the optimum temperature for maximum L-asparaginase activity but around this temperature 
at lower or higher value, the enzyme activity was decreased. Similar results was obtained by other investigators $[61,64]$ indicated that optimum activity of L-asparaginase was obtained at $37^{\circ} \mathrm{C}$. L-asparaginase of Aspergillusterresk was active at $50^{\circ} \mathrm{C}[33]$ and Bacillus sp. was active at $80^{\circ} \mathrm{C}[21]$.

\subsection{Effect of pH on L-Asparaginase Stability}

Determination of $\mathrm{pH}$ on enzyme stability was important for the maintaining the enzyme conformation. This may differ among the kind of enzyme and the organism. Figure (7): The enzyme was stable at alkaline pH 8.5 and nearly remains $100 \%$ activity after incubation for 30 and $60 \mathrm{~min}$ at $37^{\circ} \mathrm{C}(\mathrm{Fig}$. 7 ). The enzyme remains $55 \%$ and $40 \%$ activity at $\mathrm{pH} 11$ for 30 and $60 \mathrm{~min}$ respectively. The L-aspargenase enzyme obtained from seed was more stable at alkaline $\mathrm{pH}$ than at the acidic one. The enzyme was maximally stable at pH range from 8.0 to 9.0. Optimum pH for L-asparaginase stability was studied at different pH values (3.0-11.0) and the residual activity was determined. Results in Figure (7) showed that L-asparaginase has maximum residual activity (95\% and 96\%) and more stable at $\mathrm{pH} 8.0$ and 8.5 respectively [42]. The residual activity was decreased with the pH values increased or decreased than optimum $\mathrm{pH}$ values. Enzymes like other proteins, are stable over only a limited pH range. Proteases are stable over detected $\mathrm{pH}$ range but around these $\mathrm{pH}$ modification and denaturation of protein structure were obtained [14,33]. L- asparaginase was stable at pH ranged (4.5-11.0) as previous reported [50, 71 ] but more stable was observed with alkaline $\mathrm{pH}$. L-asparaginase of some bacteria was, however, most stable at the $\mathrm{pH}$ range of 5-9 [2, 5, 42]. The enzyme showed stability at alkaline $\mathrm{pH}(\mathrm{pH} 7.5-9.0)$ as it retained 90\% of its original activity when incubated up to 24 h (Figure 6). However, These findings are in agreement with those of other studies $[5,12,13]$ reported the optimum $\mathrm{pH}$ of L-asparaginases from several plants ranged from 8.0 to 8.5 .

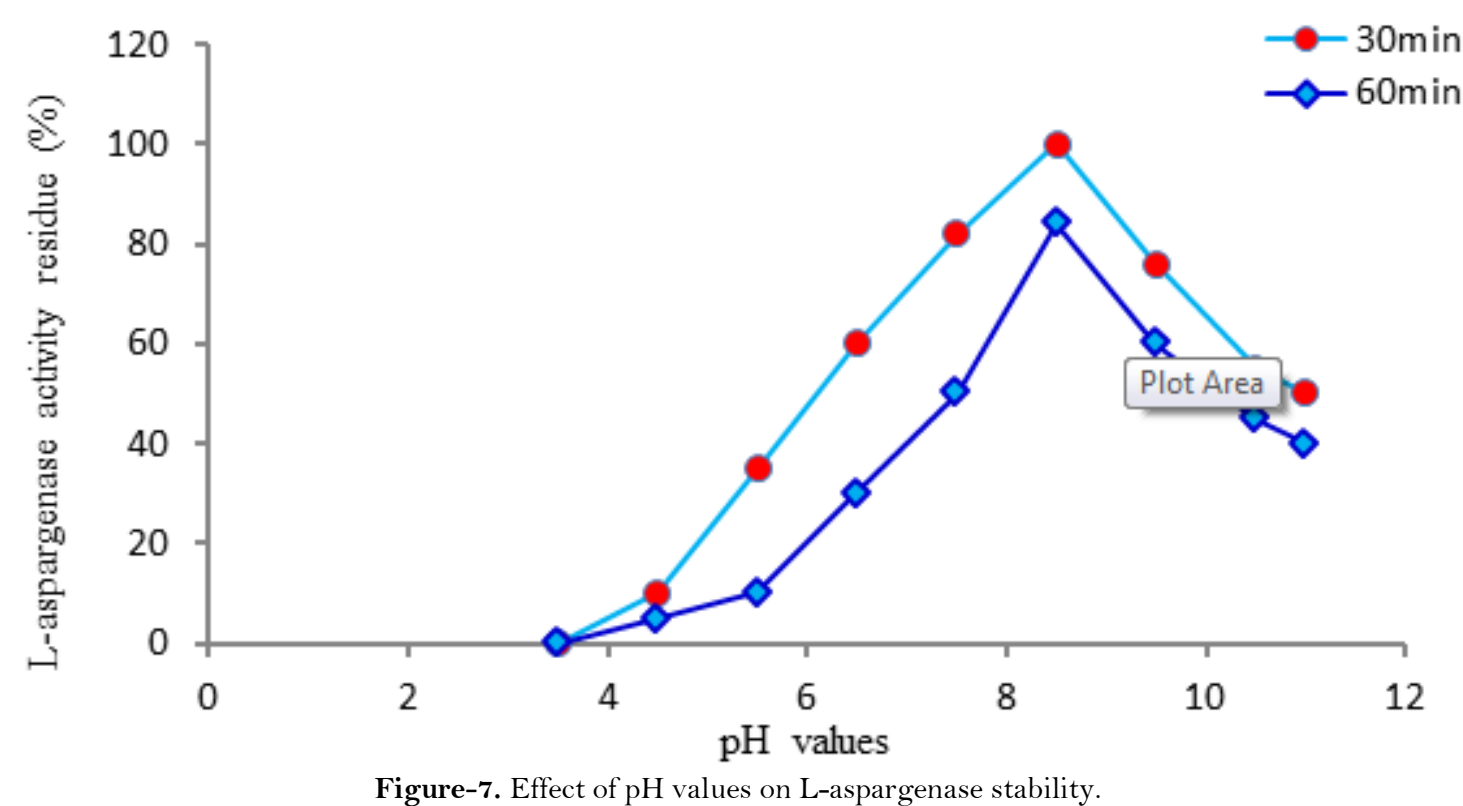

\subsection{Effect of Temperature on L-Asparaginase Stability}

The effect of temperature on enzyme stability are present in Fig.(8).Results indicated that the enzyme activity was not lost when incubated at $40^{\circ} \mathrm{C}$ for 30 and $60 \mathrm{~min}$. The residual activity is nearly $100 \%$ at this temperature. At $80^{\circ} \mathrm{C}, 69 \%$ and $60 \% \mathrm{~L}$-aspargenase activity for $30 \mathrm{~min}$ and $60 \mathrm{~min}$ was remains respectively. L-asparaginase activity and residual enzyme activity were determined at different temperature values (15-90). Results in Figure (9) showed that L-asparaginase was stable at $40^{\circ} \mathrm{C}$ and maximum residual activity $(75 \%)$ was observed at this temperature. The residual activity of the enzyme was decreased around lower or higher optimum temperature for enzyme stability $\left(40^{\circ} \mathrm{C}\right)$. L-asparaginase of AspergillusterresKLS2 retained all of its activity through incubation at $70^{\circ} \mathrm{C}$ for 30 and 60 minutes [33]. Other investigators [3]. noticed that L-asparaginase of marine Vibrio lost approximately $20 \%$ of its activity through incubation at $60^{\circ} \mathrm{C}$ for 30 minutes. The enzyme activity was stable up to $37^{\circ} \mathrm{C}$ after incubation for $1 \mathrm{~h}$. L-asparaginase from $V$. unguiculata was stable up to $40^{\circ} \mathrm{C}$ after incubation for $15 \mathrm{~min}[10,21$, 43]. then remaining activity decreased when the enzyme was incubated at temperature values more than the optimum for stability $\left(40^{\circ} \mathrm{C}\right)$, and then L-asparaginase began to lose its activity after incubation at temperature $45^{\circ} \mathrm{C}[36]$. The decrease in the enzyme activity with the increase in temperature may lead to the denaturation of enzyme by destructing the three dimensional structure of protein and that cause a change in the active site which leads to inactivation of the enzyme at high temperatures. Crude and partially purified enzymes are more stable than purified enzymes due to the existence of carbohydrates and other proteins protecting them [24, 50]. Moreover, enzyme that work either at extreme $\mathrm{pH}$ values or high temperature are now of biotechnological interest, therefore, purification of enzymes with these properties presents genuine commercial opportunities and a valuable contribution to the field of biotechnology. Enzyme that work either at extreme $\mathrm{pH}$ values or high temperature are now of biotechnological interest. 


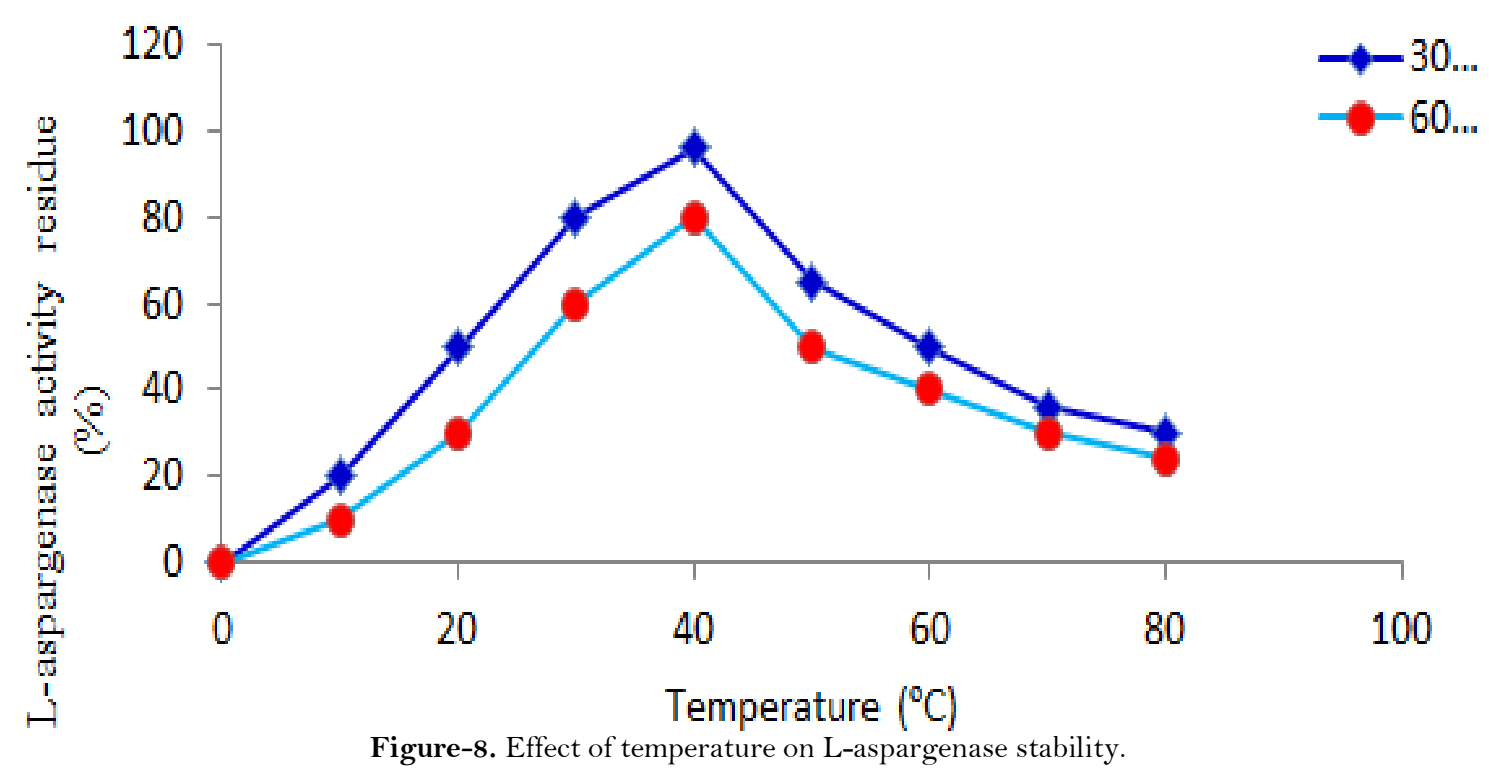

\subsection{Cytotoxicity and Anticancer Activity ofL-Aspargenase}

The present study was carried out to evaluate the potential efficacy of Vignaunguiculata seed L-aspargenase against four different carcinoma cell lines in vitro (Figures 9, 10). The effect of L-aspargenase used in vitro cytotoxicity test was done to identify activity of the L-aspargenase in growth inhibition of four different carcinoma cell lines, colon (HCT-116), liver (HEPG2),cervical (HELA) and Brest (MCF7). Results showed that L-aspargenase has higher effective in inhibition against HEPG2 and HCT-116but lower effective against HELA and MCF7 cancer cell lines. L-aspargenase exhibited more effectiveness on growth inhibition of HEPG 2 but less on HCT 116 cancer cell lines (Figure 9). Results also showed that L-aspargenase was effective in inhibition of HELLA but slightly effective against MCF7 cancer cell line (Figure 9). The effect of L-aspargenase on HEPG2 and HCT 116 cancer cell line in vitro revealed that L-aspargenase capable on inhibit cell proliferation of human HEPG2 and HCT-116. Results in Figure (10), illustrate the dose response (IC50) of L-aspargenase on HEPG2, HCT-116, HELA and MCF7. The present results showed the growth inhibitory effect of L-aspargenase on HEPG2, HCT116 and HELLA. The data show that L-aspargenase have a higher cytotoxic activity against HEPG 2 and HCT 116 than the other cell lines (Figures 9,10). These results indicated that L-aspargenase have more anticancer effect against HEPG2 and HCT116. The L-aspargenase reduced the survival fraction to $50 \%$ where less than $10 \mu \mathrm{g}$ of Laspargenase killed $50 \%$ of cancer cells, particularly HEPG2, HCT116 and HELLA respectively (Figure 10). Similar results were found by other workers $[23,32,34,36]$. It can be observed that L-asparaginase inhibits cell proliferation of HEPG 2 and HCT-116 (human cancer cell lines) that could arrest the cell cycle and generate apoptosis, which explain the in vitro anti-proliferative effect of L-asparaginase. Cancer cells exhibit rapid growth and cell division, and therefore have an increased nutritional need than normal cell [23, 51]. In most human cells deficiency, L-asparagine is produced from aspartic acid and glutamine by asparagine synthetase. Since tumor cells need asparagines for growing and functioning whereas normal cells can produce enough of this amino acid to meet their requirements with the help of asparagine synthestase $[17,35,51]$. Tumor cells are destroyed by Lasparaginase without significant damage to normal cells $[11,27]$. Most of cancer cells are dependent on Lasparagine an amino acid essential for lymphoblasts growth. However, normal cells are able to synthesize Lasparagine and thus are less affected by its rapid depletion due to treatment with L-aspargenase, since lymphoblasts are unable to produce L-asparagine which leads to death of these cells [68]. The data presented in Figure 9,10 show that the L-aspargenase exhibited high cytotoxic activity. The IC50 values for enzyme confirmed the most potent Several plant species having disease preventive and therapeutic properties. This observation is of particular importance in many vegetables and fruits and the association of vegetable and fruit consumption with reduced cancer risk has been reported $[32,56,72,73]$. The present results indicate that L-asparaginase produced in the present study may serve as a natural chemotherapy target for the treatment of colon and HCC. Lasparaginase may be reduce the possibility of side effects over anticancer therapy courses.

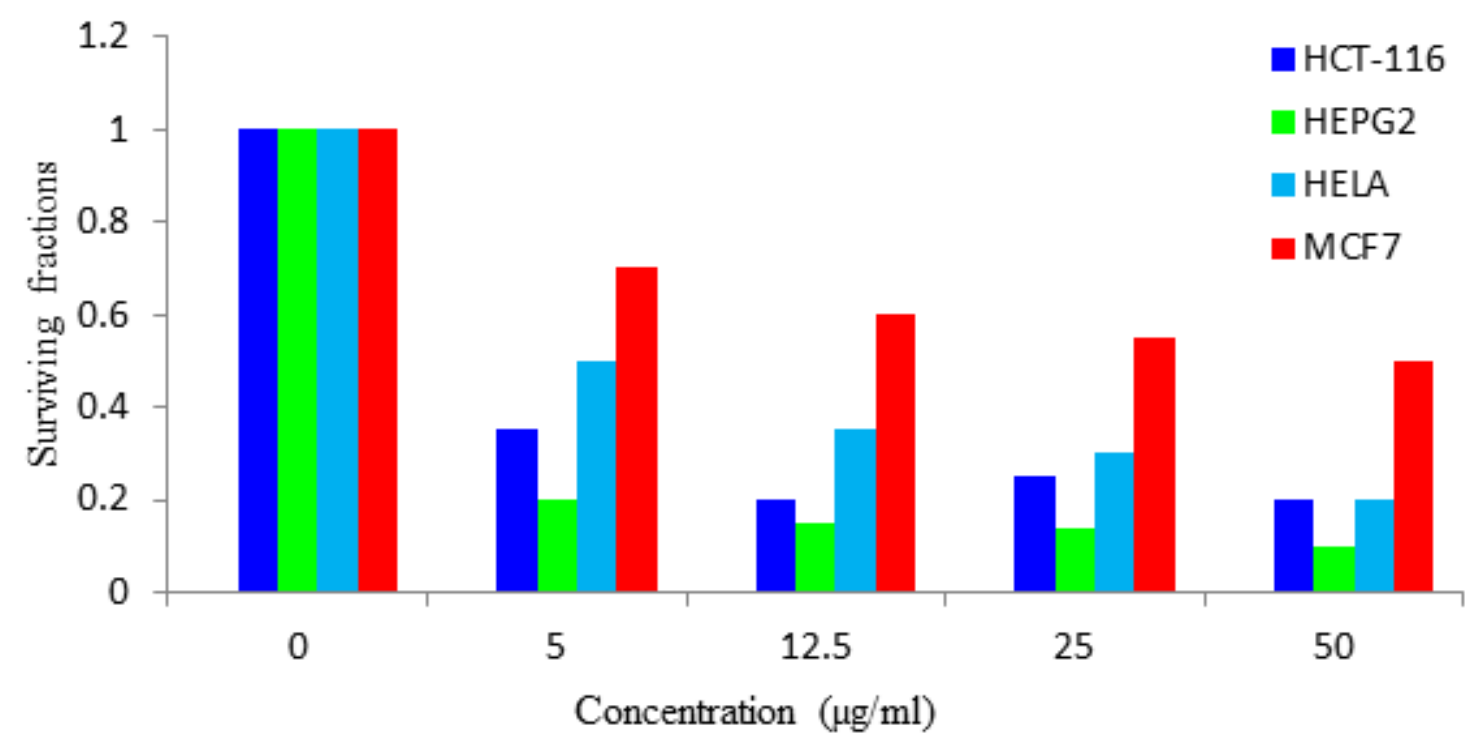

Figure-9. Cytotoxic effects of L-aspargenase on carcinoma cell lines. 


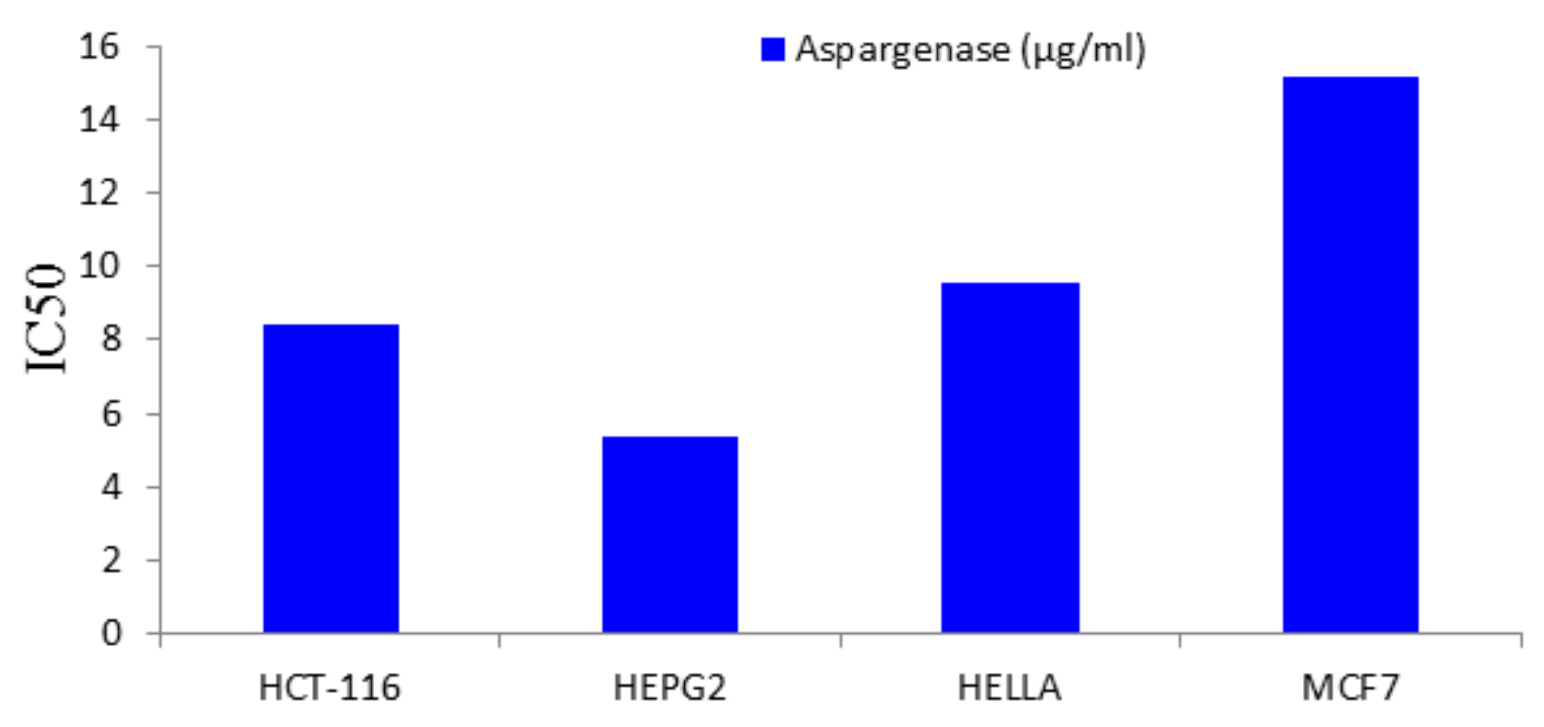

Carcinoma cell lines

Figure-10. IC50 of L-aspargenase against carcinoma cell lines.

\section{Conclusions}

Vignaunguiculataseeds consider to be efficient and suitable source for L-asparaginase production under optimum conditions. L-asparaginase extracted from Vignaunguiculata seed can easily purified by using ion exchange and gel filtration chromatography techniques. Purified active L-asparaginase has closed molecular weight of $68,5 \mathrm{kDa}$ and was stable and active at $\mathrm{pH} 8.5$ and $37^{\circ} \mathrm{C}$ for $30 \mathrm{~min}$. Purified L-asparaginase produced in the present study has cytotoxic effect against four different carcinoma cell lines. L-asparaginase showed good stability over a wide range of physiological conditions as $\mathrm{pH}$ and temperature can be reduce the possibility of side effects of anticancer therapy over course treatment.

\section{References}

[1] J. C. Rogez, R. Plaquet, and G. Biserte, "Guinea pig liver L-asparaginase: Separation, purification, and Intracellular localization of two distinct enzymatic activities," Biochimica Biophysica Acta Journal, vol. 410, pp. 370-381, 1975. View at Google Scholar

[2] D. Borek, K. Michalska, K. Brzezinski, A. Kisiel, J. Podkowinski, D. T. Bonthron, D. Krowarsch, J. Otlewski, and M. Jaskolski, "Expression, purification and catalytic activity of lupinus luteus asparagine $\beta$-amidohydrolase and its escherichia coli homolog," European Journal of Biochemistry, vol. 271, pp. 3215-3226, 2004. View at Google Scholar | View at Publisher

[3] P. Dhevagi and E. Poorani, "Isolation and characterization of L-asparaginase from marine actinomycetes," Indian Journal of Biotechnology, vol. 5, pp. 514-520, 2006. View at Google Scholar

[4] V. P. Oza, "Isolation and characterization of L-asparaginase from plant species of solanaceae and fabaceae," Ph.D Thesis, Collage of Science. Sardar University, India, 2009.

[5] V. B. Ramble, R. R. Srinivasa, S. B. Prita, C. N. Khobragade, and B. S. Dawane, "Purification of L-asparaginase from bacteria erwinia carotovora and effect of a dihydropyrimidine derivative on some of its kinetic paramerers," Indian Journal of Biochemistry ङे $^{\circ}$ Biophysics, vol. 43, pp. 391-394, 2006. View at Google Scholar

[6] E. N. Ebeid, M. M. Kamel, and B. A. Ali, "Detection of anti-asparaginase antibodies during therapy with E. coli asparaginase in children with newly diagnosed acute lymphoblastic leukemia and lymphoma," Journal of the Egyptian National Cancer Institute, vol. 20, pp. 127-133, 2008. View at Google Scholar

[7] M. E. Moharam, A. M. Gamal-Eldeen, and E.-S. S. T., "Production, immobilization and anti-tumor activity of L asparaginase of bacillus sp. R36," Journal of American Science, vol. 6, pp. 157-165, 2010. View at Google Scholar

[8] M. El-Sayed, S. T. El-Sayed, W. G. Shousha, A. N. Shehata, and S. S. Hanafy, "Purification, characterization and antitumor activity of L-asparaginase from chicken liver," Journal of American Science, vol. 7, pp. 439-449, 2011. View at Google Scholar

[9] A. M. Majeed, "Extraction, purification and characterization of L-asparaginase from withania somnifera ripe fruits," M.Sc. Thesis, Baghdad University. College of Science, Iraq, 2011.

[10] A. E. M. Mohamed, "Purification and characterization of vigna unguiculata cultivar asparaginase," Egyptian Journal of Biological Research, vol. 11, pp. 29-36, 2009. View at Google Scholar $\mid$ View at Publisher

[11] V. P. Oza, S. Kumar, P. P. Pritesh, and R. B. Subramanian, "Anti-cancer properties of highly purified L-asparaginase from withania somnifera L. against acute lymphoblastic leukemia," Applied Biochemistry and Biotechnology, vol. 160, pp. 1833-1840, 2010. View at Google Scholar | View at Publisher

[12] Z. A. Khalaf, N. K. Al-Ani, and H. M. Jasim, "Optimum conditions for asparaginase extraction from pisum sativum sub spp," Iranian Journal of Plant Physiology, vol. 2, pp. 517-52 1, 2012. View at Google Scholar

[13] M. Shanmugaprakash, C. Jayashree, and V. Vinothkumar, "Biochemical characterization and antitumor activity of three phase partitioned L-asparaginase from capsicum annuum L," Separation and Purification Technology, vol. 142, pp. 258-267, 2015. View at Google Scholar | View at Publisher

[14] A. A. Prista and D. A. Kyridio, "L-asparaginase of thermophilus: Purification, properties and identification of essential amino acids for catalytic activity," Molecular and Cellular Biochemistry, vol. 216, pp. 93-101, 2001. View at Google Scholar

[15] K. Michalska, G. Bujacz, and M. Jaskolski, "Crystal structure of plant asparaginase," Journal of Molecular Biology, vol. 360, pp. 105116, 2006. View at Google Scholar $\mid$ View at Publisher

[16] A. M. M. Martin, R. M. Samuel, and L. M. Israël, "Chemical composition and nutritional evaluation of a cowpea protein concentrate," Global Advanced Research Journal of Food Science and Technology, vol. 2, pp. 35-43, 2013. View at Google Scholar

[17] P. J. Lea, S. A. Robinson, and G. R. Stewart, The enzymology and metabolism of glutamine, glutamate and asparagines. In: Miflin, B. J., Lea, P. J., (Eds), The biochemistry of plants vol. 16. San Diego: Acadimac Press, 1990.

[18] K. W. Joy, "Ammonia, glutamine and asparagine: A carbon-nitrogen interface," Canadian Journal of Botany, vol. 66, pp. $2103-2$ 109, 1988. View at Google Scholar | View at Publisher

[19] M. M. Yossef and M. A. Al-Omar, "Cloning, purification and Immobilization of L-asparaginase II from E.coli W113," Asian Journal of Biochemistry, vol. 3, pp. 337-350, 2008. View at Google Scholar $\mid$ View at Publisher

[20] K. Michalska and M. Jaskolski, "Structural aspects of lasparaginases, their friends and relations," Acta Piochimica Polonica Journal, vol. 53, pp. 627-640, 2006. View at Google Scholar

[21] D. N. Kishor, Z. H. K., S. M. M., and S. S. K., "Isolation, purification \& characterization of L asparaginase from dry seeds of pisum sativum and vigna radiata," International Journal of Applied Research, vol. 1, pp. 628-631, 2015. View at Google Scholar

[22] U. K. Narta, S. S. Kanwar, and W. Azmi, "Pharmacological and clinical evaluation of L-asparaginase in the treatment of leukemia," Critical Reviews in Oncology/Hematology, vol. 61, pp. 208-22 1, 2007. View at Google Scholar |View at Publisher 
[23] O. Prakash, A. Kumar, P. Kumar, and Ajeet, "Anticancer potential of plants and natural products: A review," Amman Journal of Pharmacological Sciences vol. 1, pp. 104-1 15, 2013. View at Google Scholar $\mid$ View at Publisher

[24] S. Manna, A. Sinha, R. Sadhukan, and S. L. Chakrabarty, "Purification, characterization and antitumor activity of lasparaginase isolated from pseudomonas stutzeri MB-405," Current Microbiology Journal, vol. 30, pp. 291-298, 1995. View at Google Scholar|View at Publisher

[25] N. Verma, K. Kumar, G. Kaur, and S. Anand, "L-asparaginase: A promising chemotherapeutic agent," Critical Reviewes in Biotechnology, vol. 27, pp. 45-62, 2007. View at Google Scholar | View at Publisher

[26] H. B. El-Serag, "Hepatocellular carcinoma," New England Journal of Medicine, vol. 365, pp. 1118-1 127, 2011. View at Google Scholar

$\left.{ }_{27}\right] \quad$ R. E. Jalgaonwala and R. T. Mahajan, "Production of anticancer enzyme asparaginase from endophytic eurotium Sp. isolated from rhizomes of curcuma longa," European Journal of Experimental Biology, vol. 4, pp. 36-43, 2014. View at Google Scholar

[28] K. Umesh, S. Shamsher, and A. Wamik, "Pharmacological and clinical evaluation of L-asparaginase in the treatment of Leukemia," Critical Reviews in Oncology/Hematology, vol. 61, pp. 208- 22 1, 2007. View at Google Scholar | View at Publisher

[29] M. R. Tabandeh and M. Aminlari, "Synthesis physiochemical and immunological properties of oxidized inulin- L-asparaginase bioconjugate," Journal of Biotechnology, vol. 141, pp. 189-195, 2009. View at Google Scholar $\mid$ View at Publisher

[30] L. M. Vrooman, J. G. Supko, D. S. Neuberg, B. L. Asselin, U. H. Athale, L. Clavell, K. M. Kelly, C. Laverdiere, B. Michon, M. Schorin, H. J. Cohen, S. E. Sallan, and L. B. Silverman, "Erwinia asparaginase after allergy to E. coli asparaginase in children with acute lymphoblastic leukemia," Pediatric Blood \& Cancer, vol. 54, pp. 199-205, 2010. View at Google Scholar

[31] J. Ferlay, H. R. Shin, F. Bray, D. Forman, C. Mathers, and D. M. Parkin, "Estimates of worldwide burden of cancer in 2008: GLOBOCAN 2008," International Journal of Cancer, vol. 127, pp. 2893-2917, 2010. View at Google Scholar | View at Publisher

[32] S. A. Moharib, "Anticancer and antioxidant effects of fructooligosaccharide (FOS) on chemically induced colon cancer in rats," Electronic Journal of Polish Agricultural Universities, vol. 19, pp. 1-18, 2016. View at Google Scholar

[33] K. G. Siddalingeshwara and K. Lingappa, "Production and characterization of L-asparaginase-a tumour inhibitor," International Journal of Pharmaceutical Technology and Research, vol. 3, pp. 314-319, 201 1. View at Google Scholar

[34] M. Ando, K. Sugimoto, T. Kitoh, M. Sasaki, K. Mukai, J. Ando, M. Egashira, S. M. Schuster, and K. Oshimi, "Selective apoptosi s of natural killer-cell tumours by l-asparaginase," British Journal of Haematology, vol. 130, pp. 860-868, 2005. View at Google Scholar $\mid$ View at Publisher

[35] P. L. Lorenzi, J. Llamas, M. Gunsior, L. Ozbun, W. C. Reinhold, S. Varma, H. Ji, H. Kim, A. A. Hutchinson, E. C. Kohn, P. K. Goldsmith, M. J. Birrer, and J. N. Weinstein, "Asparagine synthetase is a predictive biomarker of L-asparaginase activity in ovarian cancer cell lines," Molecular Cancer Therapeutics, vol. 7, pp. 3123-3128, 2008. View at Google Scholar | View at Publisher

[36] Z. J. Dai, J. Gao, Z. F. Li, Z. Z. Ji, H. F. Kang, H. T. Guan, Y. Diao, B. F. Wang, and X. J. Wang, "In vitro and in vivo antitumor activity of scutellaria barbate extract on murine liver cancer," Molecules, vol. 16, pp. 4389-4400, 201 1. View at Google Scholar

[37] A. Mishra, "Production of L-asparaginase, an anticancer agent, from aspergillus niger using agricultural waste in solid state fermentation," Applied Biochemistry and Biotechnology, vol. 135, pp. 33- 42, 2006. View at Google Scholar $\mid$ View at Publisher

[38] W. Azmi, U. K. Narta, and S. S. Kanwar, "Pharmacological and clinical evaluation of L-asparaginase in the treatment of leukemia," Critical Reviewes in Oncology/Hematology, vol. 61, pp. 208-22 1, 2007. View at Google Scholar $\mid$ View at Publisher

[39] A. Sehgal, "Anticancer drug discovery using chemical genomics," Current Medicinal Chemistry, vol. 10, pp. 749-755, 2003. View at Google Scholar! View at Publisher

[40] N. A. Savitri and A. Wamik, "Microbial L-asparaginase: A potent antitumour enzyme," Indian Journal of Biotechnology, vol. 2, pp. 184-194, 2003.

[41] V. P. Talluri, M. Bhavana, K. M. V. S. Mahesh, and S. V. Rajagopal, "L-asparaginase: An ultimate anti-neoplastic enzyme," International Letters of Natural Sciences, vol. 10, pp. 23-35, 2014. View at Google Scholar $\mid$ View at Publisher

[42] A. B. Bello, M. S. Sule, and A. J. Al-Hassan, "Optimum pH and pH stability of crude polyphenol oxidase (PPO) extracted from five fruit samples commonly consumed in Kano State in Nigeria," Bayero Journal of Pure and Applied Sciences, vol. 4, pp. $26-31,2011$. View at Google Scholar | View at Publisher

[43] R. M. Daniel, M. E. Peterson, and M. J. Danson, "The molecular basis of the effect of temperature on enzyme activity," Biochemical Journal, vol. 425, pp. 60-353, 2010. View at Google Scholar $\mid$ View at Publisher

[44] G. Palmieri, C. Bianco, G. Cennamo, P. Giardina, G. Marino, M. Monti, and G. Sannia, "Purification, characterization and functional role of a novel extracellular protease from pleurotus ostreatus," Applied and Environmental Microbiology, vol. 67, pp. 27542759, 2001. View at Google Scholar | View at Publisher

[45] O. C. Aworh and S. Nakai, "Technical note: Separation of sodom apple proteinases by gel filtration," International Journal of Food Science \& Technology, vol. 23, pp. 419-423, 1988. View at Google Scholar $\mid$ View at Publisher

[46] S. C. Dharmsthiti and S. Luechai, "Purification and characterization of asparaginase from solid state culture of aspergillus Niger AK 10," International Journal of Plant Biochemistry and Biotechnology, vol. 6, pp. 1083-1092, 20 10. View at Google Scholar

[47] M. M. Bradford, "A rapid and sensitive method for the quantitation of microgram quantities of protein utilizing the principle of protein-dye binding," Analytical Biochemistry Journal, vol. 72, pp. 248-254, 1976. View at Google Scholar | View at Publisher

[48] J. Ren, H. F., and L. Zhang, "The construction and application of a new PPY-MSPQC for L-asparaginase activity assay," Sensors and Actuators Journal, vol. 145, pp. 272-277, 2010. View at Google Scholar | View at Publisher

[49] P. Andrews, "Estimation of molecular size and molecular weights of biological compounds by gel filtration," Methods of Biochemical Analysis, vol. 18, pp. 1-53, 1970 .

[50] S. A. Gaffar, "Studies on L-asparaginase from azotobacter vinelandii and mycobacterium smegmatis," A Ph.D, Thesis II Sc, Bangalore, 2005.

[51] A. Itharat, P. J. Houghton, E. Eno-Amooquaye, P. J. Burke, J. H. Sampson, and A. Raman, "In vitro cytotoxic activity of Thai medicinal plants used traditionally to treat cancer," Journal of Ethnopharmacology, vol. 90, pp. 33-38, 2004. View at Google Scholar $\mid$ View at Publisher

[52] P. Skehan, R. Storeng, D. Scudiero, A. Monks, J. McMahon, D. Vistica, J. T. Warren, H. Bokesch, S. Kenney, and M. R. Boyd, "New colorimetric cytotoxicity assay for anticancer drug screening," Journal of the National Cancer Institute, vol. 82, pp. 1107-1112, 1990. View at Google Scholar | View at Publisher

[53] M. Kozak and S. S. Jurga, "Acomparison between the crystaland solution structures of escherichia coliasparaginase II," Acta Biochimica Polonica, vol. 49, pp. 509-513, 2002. View at Google Scholar

[54] K. Aghaiypour, A. Wlodowes, and J. Lubkowski, "Structural basis for the activity and substrate specificity of erwinia chrysan themi L-asparaginase," Biochemical Journal, vol. 40, p. 5655-5664, 2001. View at Google Scholar | View at Publisher

[55] E. P. Chagaz and L. Sodek, "Purification and properties of asparaginase from the testa of immature seeds of pea (Pisum Sativum L.)," International Journal of Brazilian Archives of Biology and Technology, vol. 44, pp. 239-244, 2001. View at Google Scholar $\mid$ View at Publisher

[56] P. Arnnok, C. Ruangviriyachai, R. Mahachai, S. Techawongstien, and S. Chanthai, "Optimization and determination of polyphenol oxidase and peroxidase activities in hot pepper (Capsicum Annuum L.) pericarb," International Food Research Journal, vol. 17, pp. 385-392, 2010. View at Google Scholar

[57] Y. R. Abdel-Fattah and Z. A. Olama, "L-asparaginase production by pseudomonas aeruginosa in solid-state culture: Evaluation and optimization of culture conditions using factorial designs," Process Biochem, vol. 38, pp. 115-122, 2002. View at Google Scholar $\mid$ View at Publisher

[58] E. A. Makky, Y. C. Loh, and M. R. Karim, "Purification and partial characterization of a low molecular weight L-asparaginase produced from corn cob waste," Biocatalysis and Agricultural Biotechnology, vol. 3, pp. 265-270, 2014. View at Google Scholar|View at Publisher

[59] E. M. M. Ali, "Purification and characterization of vigna unguiculata cultivar asparaginase," Journal of Biological ResearchThessaloniki, vol. 11, pp. 29-36, 1984 .

[60] R. S. Prakasham, M. Hymavathi, and C. SubbaRao, "Evaluation of antineoplastic activity of extracellular asparaginase produced by isolated bacillus circulans," Applied Biochemistry and Biotechnology, vol. 160, pp. 72-80, 2010. View at Google Scholar | View at Publisher 
[61] P. Mohana, P. M. Radhakrishnan, and R. Balagurunathan, "Production and optimization of L-asparaginase from streptomyces sp. (TA22) isolated from Western Ghats," Journal of Chemical and Pharmaceutical Research, vol. 3, pp. 618-624, 2011. View at Google Scholar [62] S. Dogan and M. Dogan, "Determination of kinetic properties of polyphenol oxidase from thymus (Thymus Logicaulis Subsp. Chaubardii Var. Chaubardii)," Food Chemistry Journal, vol. 88, pp. 69-77, 2004. View at Google Scholar | View at Publisher

[63] J. A. Saraiva, C. S. Nunes, and M. A. Coimbra, "Purification ad characterization of olive (Olea Europaea L.) peroxidase- evidance for the occurrence of pectin," Food Chemistry Journal, vol. 101, pp. 1594-1602, 2007. View at Google Scholar |View at Publisher

[64] E. L. Bessoumy, A. A. Sarhan, and J. Mansour, "Production, isolation and purification of L-asparaginase from pseudomonas aeruginosa 50071 using solid state fermentation," Journal of Biochemistry and Molecular Biology, vol. 37, pp. 387-393, 2004. View at Google Scholar | View at Publisher

[65] A. Sivasankar, Bioseparation: Principle and techniques. New Delhi: Prentice-Hall of India, 2005.

[66] L. Eli and Co, "Gel filtration principles and methods. Amershan Bioscience. Edition AC.18-1022-18." Rerieved from www.amershambiosciences.com, 2001.

[67] J. Mukherjee, S. Majumdar, and T. Scheper, "Studies on nutritional and oxygen requirements for production of L-asparaginase by enterobacter aerogenes," Applied Microbiology and Biotechnology, vol. 53, pp. 180-184, 2000. View at Google Scholar |View at Publisher

[68] G. A. Kotzia and N. E. Labrou, "L-asparaginase from erwinia chrysanthemi 3937: Cloning, expression and characterization," Journal of Biotechnology, vol. 127, pp. 657-669, 2007. View at Google Scholar $\mid$ View at Publisher

[69] P. J. Lea, G. N. Festenstein, J. S. Hughes, and B. J. Miflin, "An immunological and enzymological survey of asparaginase in seeds of lupinus," Phytochemistry, vol. 23, pp. 51 1-514, 1984. View at Google Scholar | View at Publisher

[70] K. A. Sieciechowicz and R. J. Ireland, "Isolation and properties of an asparaginase from leaves of pisum sativum," Phytochemistry, vol. 28, pp. 2275-2279, 1989. View at Google Scholar $\mid$ View at Publisher

[71] A. L. Stecher, P. Morgantetti, I. De Deus, and J. A. Polikarpov, "Stability of L-asparaginase: An enzyme used in leukemia treatment," Pharmaceutica Acta Helvetiae, vol. 74, pp. 1-9, 1999. View at Google Scholar $\mid$ View at Publisher

[72] K. Sircar, H. Huang, L. Hu, D. Cogdell, J. Dhillon, V. Tzelepi, E. Efstathiou, I. H. Koumakpayi, F. Saad, D. Luo, T. A. Bismar, A. Aparicio, P. Troncoso, N. Navone, and W. Zhang, "Integrative molecular profiling reveals asparagine synthetase is a target in castration-resistant prostate cancer," American Journal of Pathology, vol. 180, pp. 895-903, 2012. View at Google Scholar | View at Publisher

[73] J. E. Ruby and M. T. Raghunath, "Production of anticancer enzyme asparaginase from endophytic eurotium sp. isolated from rhizomes of curcuma longa," European Journal of Experimental Biology, vol. 4, pp. 36-43, 2014. View at Google Scholar 